\title{
Materialita pohybu: vztah mezi nevidomostí a městským prostorem
}

\author{
Materiality of Movement: The Relationship between Blindness \\ and Urban Space
}

Hana Porkertová

\begin{abstract}
This article thematizes relations between visual impairment and urban space, drawing from the analytical perspective of actor-network theory (ANT). It traces the ways in which visually impaired people create specific connections with space and how they transform it. Urban space is configured for use by able-bodied persons, for whom movement within it is easy and seems to be disembodied. However, for those who defy the standardization of space, the materiality of movement is constantly present and visible, because the passages are difficult to make and are not ready in advance. These materialities, as well as the strategies that people use to make connections with urban space, differ according to the assemblages that visually impaired people create. A route is different with a cane, a human companion, a guide dog, or the use of a combination of such assistance; the visually impaired person pays attention to different clues, follows specific lines, and other information is important and available. Each configuration makes it possible or impossible to do something; this shows disability as dynamic, and demonstrates the collective nature of action, which is more visible and palpable in the case of a disabled person.
\end{abstract}

KEY WORDS visual impairment, urban space, materiality, disability, ANT, route

\section{Úvod}

Veřejný prostor, včetně prostoru městského, se má vyznačovat tím, že jde o „prostory př́ístupné každému bez omezení, tedy sloužící obecnému uživání, a to bez ohledu na vlastnictví k tomuto prostoru“ (zákon č. 128/2000 sb.). Jeho přístupnost dostává při setkání s člověkem, který je označený jako postižený, nové kontury. Městský prostor často není pro takového člověka připravený a pohyb, který se v něm uskutečňuje, se nezřídka kdy odehrává jinými cestami a díky jiným propojením než v případě lidí, pro které je město uzpůsobeno. Tzv. tělesně zdatní lidé ${ }^{1}$ se při pohybu městským prostorem fyzicky propojují zejména se zemí - svými

Sociální studia / Social Studies 1/2019. S. 13-32. ISSN 1214-813X.

1 Koncept tělesně zdatných lidí (able-bodied people) vychází z kritické analýzy „způsobilého těla“ (ableism), tedy normy, která je regulačním ideálem. Tremain (2006) k tomu dodává: „,zdravotní postižení jsou materializovaná jako univerzální atributy subjektu skrze opakování specifických regulačních norem a ideálů ohledně funkce, struktury, kompetence, inteligence a schopnosti lidského subjektu.“ (ibid.: 39) Campbell (2009) zdůrazňuje „touhu vytvořit řád nad předpokládaným ne-řádem; chatrný, ale často přesvědčivý pokus podepřít optimální ontologie.“ (ibid.: 197) Tělo tedy pokládá za inherentně proměnlivé, nicméně zasazené do pevného řádu představy o jeho 
kroky. Ale těm, kteří nevidí, často samotná zem nestačí. S prostorem je třeba spojit se i na jiných místech.

V následujícím textu jsem se zaměřila na navazování vztahu mezi nevidomostí a městským prostorem a na to, jaké procesy se při tomto navazování uskutečňují. Sociologický nástroj, který mi umožňuje tyto dynamické procesy zachytit a artikulovat, pro mě představuje teorie aktérů-sítí (ANT) ${ }^{2}$. Sít' je způsobem, ,jak něco popsat, a nikoli to, co je popisováno“ (Latour 2005: 131). Jde především o to, jak je propojována, jak se tímto propojováním vytvářejí a proměňují specifické jednotlivosti ${ }^{3}$, které v této síti něco dělají, a jaká další spojení již existující propojení umožňují a znemožňují vytvářet. Spojení jsou značně heterogenní a konkrétní jednotlivosti v nich získávají své formy a atributy - jedná se o konkrétní uspořádání vycházející z heterogenity sítě, nikoli o homogenní singularity. Nelze je tedy jasně dělit na technologické, sociální či lidské, ale vytvářejí materiálně-sémiotické konstrukce (Moser 2006: 376), jež se promítají do specifických konfigurací subjektivity, tělesnosti, postižení ${ }^{4}$ či prostoru. Téma konstrukce i nemožnost rozdělení na materiální, sémiotické a biologické entity, které by těmto konstrukcím předcházely, jež je ústřední pro prŕístupy inspirované poststrukturalistickou filozofií ${ }^{5}$, je podnětné i pro disability studies. Otázce disability se dostává

stabilitě a jednotě. Disabilita narušuje tento řád i další křehké hranice a koncepty, které jsou kolem autonomního, nezávislého subjektu opředeny - celkové zdraví a schopnost, kompetence, dokonalost, produktivitu, hodnotu (ibid.).

2 Ačkoli je v českém prostředí užívanější termín „teorie sítí(-)aktérů“, inspirována Stöckelovou (2016) jsem se rozhodla pro doslovnější překlad „teorie aktérů-síti““, který více vyjadřuje podstatu tohoto analyticko-metodologického př́istupu. Úskalím používání ANT je představa sítě skládající se z jednotlivých aktérů, která často ústí v jejich prosté vyjmenování. V ANT jde ale především o sít’ovou dynamiku - tj. že sítě umožňují aktérství, což odkazuje ke kolektivnímu aktérství, o kterém bude řeč dále $\mathrm{v}$ textu.

3 Vycházím z českého překladu Konopáska (Moser a Law 1998), který hovoří o „specifických jednotlivostech“ či „konkrétní jednotlivostech“. V původním textu Moser a Law používají termín "specificities“.

$4 \quad$ S príchodem tzv. sociálního modelu (Oliver 1983) byl patrný odklon od individuálního zdravotního postižení jako funkčního limitu těla k disabilitě jako systému sociální diskriminace. Přes pozitiva, které sociální model přinesl, se na něj snesla celá řada výtek mírících z různých paradigmatických pozic. Z poststrukturalistické analytické perspektivy se stalo problematické rozdělení na disabilitu a zdravotní postižení (,impairment"), kdy jedno je konstruované, zatímco to druhé nikoli (Corker 1999; Tremain 2006). Konceptualizace termínů disabilita a postižení se v mém textu nabývají $\mathrm{v}$ průběhu psaní. K disabilitě přistupuji zejména pokud hovořím o ne/schopnosti, postižení více vnímám jako znepokojivý termín vyjadřující negativní vymezení vůči normě (Kolářová 2012). Podrobnější rozdíly mezi jednotlivými koncepty řeším ve své disertační práci.

5 Tento text částečně vychází z mé disertační práce, kde jsem místo ANT používala deleuzo-guattariovskou analytickou perspektivu. Právě v kapitole o pohybu prostorem se mé deleuzo-guattariovské přemýšlení velmi posouvalo do módu ANT, která z Deleuze a Guattariho do jisté míry čerpá (Latour 1999; Smith 2007). Pro záměry tohoto textu by nakonec nebylo účelné věnovat tolik prostoru vysvětlování klíčových bodů deleuzo-guattariovské filozofie a rozhodla jsem tento prostor raději věnovat vztahům mezi empirickými daty. Jakkoli jsou některé části podobné mé kapitole v disertaci, jiné se s odlišným analytickým prŕstupem i slovníkem liší, něco ztrácejí a něco získávají. 
v rámci ANT (a STS - science and technology studies) stále větší pozornosti (Adam a Tatnall 2010; Galis 2011; Mauldin 2017; Moser 2005, 2006), což se týká i českého prostředí (Synek a Carboch 2014; Synek 2018). Ani o prostoru se z této perspektivy neuvažuje jako o něčem, co by propojením předcházelo, ale jednotlivými spojeními se prostor tvoří (Murdoch 1997; Greenhough 2010).

Následující stat' vychází z etnografického terénního výzkumu a nestrukturovaných rozhovorů z let 2014-2017 se šesti nevidomými lidmi - Evou, Jessie, Romanem, Milanem, Helenou a Vlastou. V̌̌ichni mí komunikační partneři kromě Milana někdy v průběhu svého života hůřre či lépe viděli, což, pokud je to relevantní, dále tematizuji v textu. Některých rozhovorů a pozorování se zúčastnil i vidící př́tel jedné z komunikačních partnerek Filip a její vodící pes Nessie. V organizaci zaměstnávající v dílně lidi se zrakovým postižením (dále jen Organizace) jsem uskutečnila kratší rozhovory s jejími zaměstnankyněmi. Při svém výzkumu jsem se zaměřila na to, jaké nevidomí lidé používají strategie na vytváření spojnic s prostorem, jak se proměňuje časoprostor s těmito strategiemi a jak se mění známý prostor na neznámý a naopak. To pak otevírá dveře pro další tázání. Jak nevidomí lidé zpř́itomňují prostor? Jak jej zhmotňují a rozeznívají? A jakou podobu dostává aktérství?

\section{Cesty známé a neznámé a tělesnost trasy}

Přemýšlet o prostoru i disabilitě z perspektivy ANT znamená zachytit vzájemná propojování i rozpojování při pohybu prostorem i přechody mezi konkrétními jednotlivostmi, které jsou někdy hladké a jindy obtížné, někdy předpokládané a jindy nečekané, někdy dostupné a jindy nikoli. Přechody si lze představit jako místa, kde skončí propojení s jednou (ale i více) specifickou jednotlivostí a je třeba navázat je s další(mi). Moser a Law (1999) si všímají snadností či obtížností pohybování se mezi nimi, kde snadné, dobré přechody (,good passages vs. bad passages") jsou uzpůsobené tělesně (a mentálně) zdatnému subjektu. Hladkost, a díky tomu neviditelnost těchto přechodů pak umožňuje hovořit o odtělesněném subjektu, jehož rychlé přemístování se zdá být autonomní a nezávislé (Moser 2006).

Já: Milane, je pro tebe zvláštní, že se ty lidi, který viděj, pohybujou bez hůlky?

Milan: Já si myslim, že tak jako nevidící bez hůlky, když sou si někde jistý, kde to znají. Akorát oni k tomu používaj ty oči, to jim dává tu jistotu, že to jakoby znaj všude. Takhle to vidím já. Já vnímám, že když jdou hodně rychle, tak tam je cejtit v tý chůzi ta samozrejmost, jistota. (rozhovor; 8. 11. 2014)

Město je rozvrženo tak, aby se propojení s ním a přechody $\mathrm{v}$ rámci něho uskutečňovaly díky zraku. S jeho pomocí lze navíc u známých konfigurací - sítí, kde jsou umožněny dobré přechody - improvizovat. Vytvořit spojení s překážkou či volným prostorem je možné na daleko větší vzdálenost, a tím pádem mnohem dřive než lze provést fyzický dotek. Mezera mezi viditelným a hmatatelným nemusí být zaplněna. Vidícímu člověku však dodává jistotu nejen schopnost improvizovat. Pohyb v prostoru se odehrává vyznačenými cestami. Po chodnících jasně oddělených od silnic, po přechodech pro chodce směrujících pěší na konkrétní místa, kde lze bezpečně silnici přejít a znovu se napojit na specifickou jednotlivost 
chodníku. Hladkost, i když ne nutně rychlost přechodů ulehčují semafory. Na každý pohyb je pamatováno.

Pohyb městským prostorem se odehrává s jistotou zejména proto, že tento prostor je konfigurován známými cestami, uzpůsobenými na tzv. zdravého člověka - jakoby to znaj všude. Tím zároveň ony konfigurace vytvářejí takového člověka jako schopného, s jeho věděním i standardizovaným pohybem těla, a ten, pro koho jsou přechody obtížné, je nedostatečný (Moser a Law 1999; Moser 2006). Hladké přechody jsou pro vidícího člověka ve městě již připraveny, nevytváŕí se až na místě, jen díky očím. V systému, se kterým není člověk sžitý, pak přicházejí zmatky, záseky, kolize. Přechod do levostranného prostředí je pro člověka zvyklého pohybovat se vpravo zmatený, nešikovný a nejistý. Když na složité křižovatce přestanou fungovat semafory, které zajištují hladké přechody, doprava kolabuje.

Znát to všude tak vyjadřuje znát to dřiv. Ve známém rozvržení a se známými přechody i nevidomí lidé získávají jistotu. Žádný z mých komunikačních partnerů a partnerek nechodí s hủlkou či vodícím psem doma či v dalších budovách, kde se již vyznají. Např. i po hotelu je po nějaké době člověk schopný se pohybovat sám. Komunikační partner Roman říkal, že když je doma (u sebe v bytě či v domě rodičů), tak by nikdo ani nepoznal, že nevidí. Vnitřní prostory a domov obzvlášst jsou místy, která se nemění často, a když už, tak většinou s vědomím dotyčného člověka. Ví se tedy, kde se ony přechody nalézají. Ve venkovních prostorách, které se navíc neustále mění, se vyskytuje množství předmětů, s nimiž spojení dopředu vytvořená nejsou, nejsou součástí paměti. Je tedy třeba ona propojení vytvořit.

Sebejistý pohyb se má odehrávat automaticky, především v hlavě, přestože v prostoru nelze skákat ani se teleportovat a tělo je s ním v neustálém kontaktu. Fyzičnost jako taková je ve městě nežádoucí, $\mathrm{k}$ její eliminaci slouží jak dopravní prostředky, tak i výtahy či eskalátory, které umožňují neuvědomování si těla. Na fyzickou únavu a těžké nohy je místo při sportu či výletech v prírodě. Nicméně „,materialita vzdoruje postiženým subjektům: vždy jsou tu obtížné přechody, chybějící návaznosti a problematická těla“ (Moser 2006: 385). Pro nevidomého člověka je tak materialita pohybu neustále př́itomná.

Konceptem, jak tuto materialitu zachytit, je trasa. Umožňuje sledovat konkrétní spojení a přechody v prostoru a vyjádřit pohyb, který se v něm odehrává. Do trasy je zapojeno mnoho vzájemně provázaných elementů a překračuje jak místní, tak časové určení, které nemusí znamenat „tady a ted““. Nevidomí lidé potřebují vyvinout strategie, které co možná nejhladší přechody vytvoří již dopředu, stejně tak jak jsou připraveny pro člověka, který je pro město standardní. Trasa často začíná už doma, kde je nutné si ji mentálně projít a získat informace o přechodech, tj. zjistit, na jakých místech lze navázat spojení se specifickými jednotlivostmi, jejichž série člověka dovede na určené místo. Tato príprava se promítá do samotné trasy, a je tedy její součástí.

Způsobů, jak získat informace, je několik. Jedním z nich je popis tras pro nevidomé lidi, který je možné stáhnout na internetu a který je vytvářen člověkem, jenž sám nevidí. To ale neznamená, že musí vyhovovat každému dalšímu nevidomému člověku, a např. Eva si radši nechá trasu popsat svým vidícím přítelem Filipem, s nímž je sehraná a oba vědí, jaké informace jsou pro ni důležité. Osman a Pospíšilová (2016) rozebírají rozdíl mezi vizuálním popisem a následným zaživáním trasy nevidomými lidmi. Ten se nicméně týká i lidí vidících, 
přestože jinak - popis a vlastní zkušenost se liší vždy, rozdíl je v tom, jaké informace jsou pro orientaci důležité a jak s nimi lidé následně pracují. Vidící člověk může snáze mezi popisem a trasou najít a vytvořit spojnice (např. v informaci ,jděte kolem školy“, „vydejte se podél červené budovy“ - ale čím více podobných informací, tím větší pravděpodobnost jejich zapomenutí a zmatení), což je pro člověka, který nevidí, obtížné.

Aby učení se a vytváření trasy nestálo na nejisté koherenci mezi statickým popisem nereagujícím na momentální situace, ani na polohu nevidomého těla a fyzickým prostorem, jejichž vztah je někdy obtížné navázat, je dobré popis se zaživáním trasy rovnou propojit. Pokud má Roman v plánu docházet někam pravidelně, využije strategii, která počítá se zrušením rozdílu mezi prvotním popisem a následným absolvováním cesty, připraví bezpečné a co nejhladší prechody a umožňuje mu ji po nějaké době vykonat samostatně. Touto strategií je nácvik trasy $\mathrm{s}$ asistentem či asistentkou, který poskytuje Organizace.

Roman: Sem se učil chodit do armyshopu, blackmet shopu a takovejch obchodů důležitejch pro mě. Já: A kde je ten armyshop?

Roman: U Mrkvový. To je docela sranda, že když přecházim, tak musim jít podél zábradlí, na konci zábradlí se jde o pětačtyřicet stupňů doprava a tam to není ani kolmo jakoby a potom přejít tu silnici, co vede od mostu směrem k náměstí. Ale dobrý, už sem se to naučil, mě nejprve provedl asistent a musí si bejt jistej, když mě něco učí, tak musí vědět, že bezpečně se dostanu. Tak sme si to dvakrát prošli a on naznal, oba sme naznali, že už to zvládnu úplně sám od tý doby. (rozhovor; 14. 10. 2014)

Trasa a spojení, která ji vytváŕejí, vznikají v kombinaci s asistentem, ukládají se do paměti mysli i těla Romana, pro jistotu dojde k zopakování cesty a její utvrzení se završí společným prohlášením, že je Roman již připraven absolvovat ji sám. To, jak trasa vstupuje do těla, je pro nevidomého člověka klíčové. Brambring (1982 citován in Fryer, Freeman a Pring 2013: 125) srovnával popisy tras mezi nevidomými a vidícími lidmi, a zatímco vidící dávali důraz na prostředí, lidé, kteř́ neviděli, se zaměřli při svém popisu na detailní informace o vzdálenosti a rotaci těla, jak bylo patrné i u Romana. Jak vidící, tak nevidící lidé se zaměřili na spojnice, které jim umožňují pohyb v prostoru. Tělesná pamět’ je důležitá i pro komunikační partnerku Jessie:

Já sem prostě věděla „šest kroků, jeden oblouček“. Ne že bych to vědomě počítala, ale někdy mi to naskočí samo, nebo že si počitám schody. Ale taky úplně samo. (rozhovor; 24. 9. 2014)

Tělesná pamět' se vytváŕí opakováním a praxí a postupně se vyvine v automatickou dovednost (Fuchs 2013: 9-22; Osman a Pospíšilová 2017). Tělo a tělesná pamět’ jsou tak součástí trasy, která není odtělesněná a jako taková je i těžko přenositelná.

Prvotní nácvik známých tras je důležitý i pro Evu s její vodící fenkou Nessie - přestože je především na člověku, aby psovi říkal, zda má jít doleva či doprava, Nessie je schopná zapamatovat si cestu i sama a dvojici stačí si jednou projít s Filipem či rodiči cestu a potom už tam trefí samy. Do uspořádání člověka a vodícího psa tak v procesu učení se nové trase vstoupil i Filip nebo rodiče. 
Ne vždy je možné si trasu detailně nacvičit a projít, vytvořit spojení dopředu a vyznat se v přechodech. Ochotu vydávat se na neznámá místa ovlivňuje otevřenost ke karambolům, nekontrolovatelným situacím, i spoléhání na št’astnou náhodu a na to, že to nějak dopadne, a kdyžtak je možnost zeptat se okolních lidí (Milan, terénní poznámky; 19. 10. 2014). Existuje výrazný rozdíl mezi nacvičenou a dobře kontrolovatelnou trasou, která je zafixovaná v paměti a definuje tedy př́ítomnost jako provázanou s minulostí, a trasou, která definuje pouze př́ítomnost, a je tedy nepředvídatelná. Mezi těmito trasami nicméně nemusí být kontrast. Někdy stačí mít povědomí o určitých konkrétních jednotlivostech a přechodech. Když má Milan v plánu někam se dostat, má nějakou představu jak, ale detaily nechá na situaci. Jedná se o odvahu $\mathrm{k}$ nejistotě. Snaha nejisté přechody eliminovat nicméně často ústí v to, že se nevidomí lidé raději neznámými cestami sami nevydávají. Již jsem uvedla příklad, jak si Eva nechá Filipem popsat trasu - konkrétně se jednalo o budovu v centru města, ve kterém Eva dlouho žije. V centru se vyznala a měla aspoň hrubou představu a záchytné body. Ale k neznámým situacím dodává:

Eva: Ani v mym městě, že bych se vydala do čtvrti, kterou neznám, a vydat se na nějakou neznámou adresu, to si nedovedu představit. To je hrozně složitý.

Já: Ty používáš hodně ten iPhone, ne?

Eva: Jo, po tom centru, kde ty ulice znám, po tom centru chodil člověk celej život a zná ty ulice, která kam patří, a ten iPhone ti řekne, na jaký seš křižovatce, že si tu mapu dokážu dát do hlavy. Ale abych třeba dojela do Zajícova a tam viděla, že mám dojet na nějakou adresu, to prostě asi nejde. Nebo já na to asi nemám tu odvahu. (rozhovor; 24. 10. 2014)

I Jessie ř́ká, že se pohybuje sama v prostorách, kde to dobře zná, a jinak je ráda s někým dalším, což ovšem není vždy možné, a proto se někdy vydá sama i na neznámá místa. Pro Milana jsou cesty do neznáma vyústěním jeho emancipace od starostlivých rodičů a babičky podpořené diskurzem samostatnosti, který byl přítomný ve vzdělávacích institucích, jimiž prošel. Roli hraje i to, že Milan nikdy neviděl a tyto situace mu tedy nepřijdou nijak zvláštní. I tak nejčastěji cestuje tam, kde to už zná, což je koneckonců i prrípad většiny situací vidících lidí opakujících své cesty do práce, do obchodu, do restaurace atd. Představa o nevidomých lidech, kteří musí nutně tápat, je tak do určité míry mýtem, protože chodí většinou trasy, které už dobře znají.

Ovšem ani známá trasa nemusí zůstat známou napořád - chápat trasu jako sít' přechodů a propojení znamená zahrnout i možnost rozpojení, změnu z dobrých přechodů na přechody špatné, nutnost je znovu nalézt a propojení opět vytvořit. Sít’ je vždy dynamická, nejedná se o statickou strukturu, v níž se člověk pohybuje, ale mění se na základě toho, jaká v ní přibývají či ubývají spojení - která jsou často nepředvídatelná, náhodná, neuchopitelná a pomíjivá. Pokud se na trase změní něco významného, co znemožní známé přechody, ze známého prostředí se stává prostředí neznámé. Schillmeier (2008) si všímá přechodů z minulosti, ztělesněné v paměti, do prrítomnosti, které nejsou v př́ípadě nevidomých lidí „hladké a rychlé - jak ukazují pohyby ,zastavit se a jít‘ či , chození cikcak“، (ibid.: 224). Nejde jen o přerod z jistoty na nejistotu, z př́mé chůze na tápání. Nevidomý člověk často tyto změny nepředpokládá, pozor si nedává a zjistí je tedy až svým tělem, což v praxi znamená, že bud' do něčeho narazí, upadne, nebo se ztrátou záchytného bodu ztratí trasu, která je na ony body navázaná, a musí 
ji navázat na jiném místě. Roman ř́ká, že má výbornou orientaci a dokázal obejít i náklad’ák a vrátit se na stejné místo. Někdy ale změna prostoru může znamenat i větší karamboly.

Eva: (o rekonstrukci na fakultě) Ty ostatní cestičky nevypadaly jako kopeček, tak mě nenapadlo, že tam jsou prudký schody dolů a já sem šup šup šup padala po těch schodech a studenti se ke mně sbíhali, ale to bylo to, že člověk i v tom terénu, o kterym si myslí, že zná, tak ho vždycky dokáže něco překvapit. A tak si představ, jak tohle člověka dokáže vykolejit, když je v terénu, po kterym chodí roky, myslí si, že ho zná, a potom se tam objeví schody. (rozhovor; 24. 10. 2014)

Tato událost se stala ještě v době, kdy Eva chodila pouze s hủlkou a vodícího psa neměla. Mnoho podobných změn je ted' schopná zaznamenat Nessie, a trasu tím pádem modifikovat podobně jako vidící člověk. Trasa je tak ve spojení s Nessie odlišná, než kdyby ji Eva absolvovala bez ní, a neznamená pouze kudy, ale je důležité, že toto kudy je vytvářeno společně s kým, potažmo jak.

Jessie vodícího psa nemá, po městě, ve kterém bydlí, nepoužívá ani hůlku, ale orientuje se podle paměti a svého zraku, který sice všechna spojení dostupná pro vidícího člověka nenaváže, ale některá ano. S podobnými nepř́ijemnostmi, kdy se na známé trase něco změní, už dopředu počítá a má své strategie, jak se v těchto situacích zachovat.

Jessie: Když sem za mostem nebo se otočim, nebo nedejbože když mě někdo otáčí, tak já potom nevim, kde sem. A když to prostředí vůbec neznám a nemám ty záchytný body pro sebe, který já si vytvořim, tak je to takovej pokus omyl a zabere to hrozně času. I tohleto je problém, když se dopravuju někde sama, i třeba na místa, kde už sem byla, tak si radši dávám větší časový odstup.

Já: A když je tam najednou nějaká překážka, rozkopaná silnice, co děláš?

Jessie: (smích) Tak když na to nejsem připravená, tak do něčeho narazim. Ono to ani nemusí bejt rozkopaný náměstíčko (jako na výstavě Naše cesta, pozn. H.P.), mně vadí i ty reklamní áčka. Když je to místo, který znám a je to tam nějaký jiný, tak se pokusim, ale mám radši, když mám těch míst víc. Když sem se přistěhovala sem, tak sem měla jednu takovou trasu, a ted' už vím, jak se dostat $\mathrm{z}$ vícero bodů $\mathrm{k}$ nám. A často se mnou chodí kamarádka, nebo sem sama s pejskem, on není vodící, ale nemá moc rád trávu, tak chodí po tom asfaltu a když chce domů, tak mě tam zatáhne. (rozhovor; 24. 9. 2014)

Vytvoření nových propojení na změněné trase vyžaduje méně či více času - a s ním i nervů, kolizí a frustrací. A ještě více času zabere zjišstování, zda se propojení navázalo se správnou jednotlivostí, prípadně vracení se zpátky k přechodům mezi nimi a zkoušení spojení jiného. Ona metoda pokus, omyl. Další strategie tkví v tom mít v záloze alternativní trasy a další možné přechody. Osman a Pospíšilová (2016) ř́́kají, že pro samostatný pohyb prostorem se jedná o ,jakési ,vědění kudy‘, nikoli o ,vědění kde“ nebo ,vědění kam““ (ibid.: 69). Pro Jessie je ale podstatné vědění „kam“, což je domů, k čemuž má několik možností „kudy“, přestože ne nutně všechny najednou. Zná více tras, jak se domů dostat, a může tím pádem improvizovat, když se na jedné trase něco změní. Někdy je toto „kam“ dosahováno s vidící kamarádkou, kdy přitom nemusejí jít trasou, na kterou je Jessie zvyklá, a v neposlední řadě i se svým psem, který sice nemá profesionální výcvik ani postroj, ale dojít domů zvládne a Jessie s ním. 
Trasa se nemění jen pod vlivem vnějších okolností - stačí, když selže jeden z jejích klíčových elementů, což je soustředění a pamět'. To se občas stává Milanovi; když je člověk nějak zamyšlenej, tak se stane, že občas zabloudí (rozhovor; 19. 10. 2014). I odlišná a komplikující podoba známé trasy dělá známé přechody obtížnými, jako např. cesta zapadaná sněhem, což zmiňuje Helena.

\section{Vytváření konkrétních propojení}

Konkrétní usporádání, kterých je člověk součástí, mají vliv na vytváření přechodů i toho, které konkrétní jednotlivosti jsou pro pohyb na trase užitečné. Na závodě pořádaném Organizací, kde jsem se seznámila s Milanem, jsem si zkusila pohybovat se s hůlkou. Část trasy, kterou šli závodníci a závodnice, jsem si poté se zavázanýma očima prošla s asistentkou.

S holí, která mi přišla poměrně těžká, se hýbe ze strany na stranu na šířku ramen. Chodí se podél zdi či obrubníku, aby člověk věděl, kam jde. Princip hủlky tak není ujištění, že jdu prázdným prostorem, ale je naopak nezbytné, aby byla na něco navázaná, aby sledovala nějaké prostředí a jeho hranice. Jít volným prostorem bylo to nejtěžší. Po schodech držím na radu asistentky hůl v tužkovém držení ve dvou třetinách její délky a „cinkám“ před sebe. (terénní poznámky; 4. 10. 2014)

Přestože je hůlka často vnímána jako nástroj, jak do něčeho nenarazit, jedná se zároveň i o to „narazit“ do správné věci a té se posléze držet. Volný prostor představuje oblast nejistého přechodu, v němž se může něco pokazit, může dojít $\mathrm{k}$ navázání spojení se špatnou jednotlivostí - špatným zábradlím, obrubníkem, či domem. Trasu jsem nejprve prošla s Milanem, který byl jedním ze závodníků. V závodě nakonec obsadil druhé místo (za dlouholetým šampiónem), přesto se na několika místech ztratil. Určení cesty měl zajišt’ovat audiopopis, který si člověk nahrál do telefonu. Trasa byla rozdělena na úseky s několika záchytnými body, kde mělo dojít $\mathrm{k}$ přechodům - kde měl člověk změnit směr či pokračovat směrem stejným, ale bez držení se linie, která se navázala až o několik metrů dál. Pokud již nešlo navázat vztah mezi popisem a zažívaným pohybem, což naznačovalo, že závodník jde špatným směrem, bylo možné se $\mathrm{k}$ záchytnému bodu vrátit, poslechnout si znovu př́slušnou část audiopopisu a pokusit se navázat spojení s jinou specifickou jednotlivostí, která snad již povede správně. Některé přechody byly snadné a Milan mezi nimi dobře procházel, jiné ale byly obtížné, jako právě onen volný prostor.

Materialita pohybu, o kterém jsem již hovořila, se netýká pouze zažívání a všudypř́tomnosti tělesnosti, ale i samotného prostoru. Vidící lidé se na trase pohybují mezi množstvím mlčících věcí, které mají zůstat nehmotné - jen pomocí zraku se ví, že tam jsou, říkají člověku, že se má od nich držet dál, a tím vyznačují trasu. I zábradlí, pokud odděluje prostory mezi chodníkem a silnicí, vysílá především signály o tom, kam se chodit nemá. De Certeau (1998: 98) hovoří o tom, že chodec přeměňuje „prostorového označujícího“ (spatial signifier) v jiného a vytváří další možnosti, jak prostoru a věcí v něm dávat nový význam. Tak jako jsou zábradlí či dům pro vidícího člověka objekty, ke kterým se nemá prŕliš přibližovat, nevidomý člověk pohybující se s hůlkou musí tyto mlčící věci rozmluvit a zhmotnit, aby mu ukázaly cestu, linii k dalšímu přechodu. Klíčová tak není bezkontaktnost, ale naopak kontakt. Každý 
z těchto objektů zní v kombinaci s hůlkou odlišně a člověk, jenž tento zvuk zná, ví, o kterou konkrétní jednotlivost se jedná. Sluchové odezvy jsou pro orientaci nevidomých lidí s hůlkou důležité (Fryer, Freeman a Pring 2013) a vedle tělesné paměti je tak stejně významná i pamět' sluchová, o které hovoří např. Milan. Ten zároveň dodává, že ho dokáže velmi rozhodit sbíječka a pak ztratí orientaci - provázanost sítě, kde se uskutečňují jednotlivé přechody, dokáže s narušením jednoho propojení zasáhnout i propojení další.

Prostor ale nerozeznívá jen hůlka. Lidé se špatným či žádným zrakem (tj. zrakem, který neumožňuje dobré prechody) mají k dispozici dálkový ovladač, který slouží k „ovládání akustických orientačních zařízení na významných budovách a dopravních prostředcích“ (www.tyflopomucky.cz). Vysílač má šest tlačítek, díky kterým lze vysílat povely, a po jejich stisknutí se krabička rozmluví. „Tlačítko 1 spouští základní informaci o názvu budovy, tlačítko 2 vyvolá doplňkovou informaci pro lepší orientaci, tlačítko 3 informuje o číslu dopravního prostředku a jeho směru, tlačítko 4 potvrzuje řidiči nástup nevidomého do dopravního prostředku, tlačítko 5 aktivuje akustické signalizace na přechodech pro chodce, tlačítko 6 aktivuje doplňkové klávesnice některých typů ele. inf. stojanů s hlas. výstupem.“ (ibid.). Aby mohly být budovy či dopravní prostředky takto rozezvučeny, respektive aby byly rozmluveny prostřednictvím ovladače, je třeba, aby byly vybaveny vysílačem s př́slušnou frekvencí a aby byl signál dostatečně silný. Pokud se spojení se zamýšlenou budovou či dopravním prostředkem naváže, je ještě třeba vytvořit sérii propojení, která člověka do této budovy dostanou.

Roman chtěl jít na nádraží na WC určené pro osoby s postižením. Věděl už dopředu, v jakých místech by se zhruba mělo nacházet, tlačítko na ovladači tak stisknul ve chvíli, kdy naznal, že signál je jednak dostatečně silný a za druhé by se dokázal v dané situaci zorientovat a místnost najít. Krabička nahlásila, že WC se nachází nahoře v chodbě po schodech vlevo. Schody zároveň slouží jako dobrý orientační bod k tomu, aby věděl, že je na správné trase. Od konce schodů je to k záchodu už jenom kousíček. Odhaduju tak šest metrů. Ale Roman takto krátkou trasu ujít nemůže, musel by přeskočit linie, se kterými se propojí. Najde hůlkou hranice chodby a poklepává. Nahoře za schody je (jak už to ve veřejných budovách často bývá) prázdné, nevyužité místo, které ničemu neslouží, ale tvoří vedle schodiště obdélníkový výklenek, jenž Roman celý obkrouží. Chvíli se tak místnosti s WC vzdaluje. (terénní poznámky; 19. 1. 2018)

Pohyb prostorem je plný přechodů, které jsou pro tzv. zdatného člověka snadné, navazují na sebe a jsou zapojeny do sítě, $v$ které se lze snadno, rychle a př́močaře pohybovat mezi specifickými jednotlivostmi, včetně napojení semaforů, zastávek MHD, podchodů i lávek, schodů, obrubníků, ale i postranních cestiček a vyšlapaných zkratek, protože lidé nejsou vždy poslušní a rádi jdou nejkratší cestou. Př́most cesty i určitý druh pohybu dostávají v případě člověka, který je nevidomý, nový obsah. Je třeba vytvořit spojení, jež fungují. Tato propojení se ale často př́ičí povědomí tzv. zdatných lidí o př́mých cestách a obecně o tom, jak se účelně pohybovat ve městě a v budovách.

Město ale nezůstává vůči různým tělům netečné. To se promítá i do veřejného prostoru, který se mění, aby se přizpůsobil potřebám různých lidí s postižením (Strickfaden a Devlieger 2012), přestože ve městech a na vesnicích stále zůstává řada špatných či nemožných přechodů. Ovšem ani ona proklamovaná bezbariérovost nemusí být ideálním řešením pro každého - jednotlivé disability se navzájem střetávají. Bariéra se překládá jako překážka či zábrana, což 
v souvislosti s prostorem asociuje něco fyzicky navíc. V prŕípadě nevidomých lidí je tomu ale často naopak, a právě volný prostor bez fyzických záchytných linií je bariérový. Usnadnění přechodů pro lidi na vozíku znamená zkomplikování pro ty, kteří nevidí, a naopak. Roman ř́kal, že ze zákona musí být na bezbariérovém přístupu hrana patnáct milimetrů - jde tak o to vytvořit přechody, které sice nejsou úplně dobré, ale zase nejsou úplně špatné pro oba typy disabilit. Nicméně vzápětí Roman dodal, že v praxi se tak často neděje a Vlasta mluvila o protežování vozejčkář̉ a o tom, že bezbariérové nájezdy a ostrůvky představují pro nevidomé lidi problém, protože nevědí, kde končí chodník a začíná silnice (Vlasta, Roman, rozhovor 13. 10. 2014).

Lidé na vozíku představují určitou ikonu postižení (Adams 2013), při tvorbě veřejného prostoru jsou jejich potřeby už často rozpoznávané a uvědomované, nicméně nevidomí lidé na to mnohdy doplácejí. Přestože ANT bývá někdy kritizována, že se nezabývá vyloučenými či méně privilegovanými aktéry (Galis 2011), Moser (2006; Moser a Law 1999) si všímá, co nebo kdo je vylučován a jaké přechody chybí k hladkému či možnému navázání dalšího propojení. Ve veřejném prostoru často chybí aktéři, kteří umožnují lidem s postižením něco dělat - mnoha lidem se špatným zrakem by např́íklad umožnilo vytvořit spojení s nápisy to, kdyby ona písmena byla větší a kontrastnější (Bradley, Hopkins a Bailey 2000). Pohyb veřejným prostorem mají usnadňovat vodící linie, které zaručují přímost či samotnou možnost pohybu. Ty však na mnoha místech chybí.

Přetváření prostoru se neodehrává pouze v územních plánech, architektuře a dopravních stavbách. Všichni lidé, kteří se prostorem pohybují, jej nějakým způsobem přetvářejí, komplikují či ulehčují přechody, vytvářejí bariéry, kterým se ostatní musí při chůzi vyhýbat. Člověk $\mathrm{s}$ hůlkou či vodícím psem kolem sebe většinou vytváŕí více prostoru, protože ostatní lidé se chtějí vyhnout př́padným kolizím. To se hodi dlouhá hůlka, že pořádně ten dav rozeženu, ty lidi (Roman; terénní poznámky; 30. 10. 2014). Roman chodí hodně rychle, sebevědomě, s holí často „máchá“, lidé před ním někdy uskakují na poslední chvíli. Milan, který se s holí učil od dětství, působí profesionálnějším, klidnějším dojmem. Akt vyhýbání ale není vždy snadný, uskakování i klidné uhýbání není koordinované a někdy přeruší nevidomému člověku místa přechodů či návazné linie. Právě díky představě, že nevidomý člověk si hůlkou hlídá volný prostor, vzniká dojem, že tedy stačí tyto podmínky vytvořit - vyhýbáním se na všechny strany.

\section{Neohraničená těla a kolektivní aktérství}

Pojímat disabilitu z perspektivy teorie aktérů-sítí - tedy soustředit se na jednotlivé přechody, propojení, konfigurace a všímat si, co tyto konstelace umožňují a znemožňují, co dělají a nedělají, znamená přjít v analýze těla a tělesnosti od esencialismu ke konstruktivismu. Tělo není rozpoznatelné samo o sobě, ale pouze skrz to, jak se chová, co dělá a jak je propojeno s ostatními těly (Malins 2004). Nemá tak žádný vnitřní význam, ale lze zkoumat, jaká spojení vytváří a co uspořádání z nich vzniklá dělají. Tato spojení se netýkají pouze ohraničeného těla člověka, ale vznikají společně s dalšími heterogenními prvky, včetně ostatních lidí, věcí či zviŕrat. Člověk s hůlkou tak nekončí tam, kde končí fyzické tělo, včetně jeho extenzí (a zároveň součástí), jako je např. ona hůlka, ale zabírá také prostor kolem sebe, který je rozsahově ještě větší než nejdelší součást těla, tedy konec hole. Tělo se s bílou holí (či s vodícím 
psem či s dalším člověkem) proměňuje - jinak se pohybuje, jsou pro něj důležitá a dostupná odlišná propojení s prostorem.

Roman: Normální hůlky pro menší lidi maj tak metr dvacet, třicet, já mám metr čtyřicet pět, takže ta je o hodně delší. Ale ještě mám o pět centimetrů delší, než bysem měl, aby sem dál viděl (úsměv). (rozhovor; 30. 10. 2014)

Kam až Roman dohlédne, závisí na délce hole. Dis/abilita tak vyjadřuje, jaká spojení může či nemůže tělo tvořit a tato spojení ani omezení zároveň nejsou fixní. Roman vypověděl, že při pohybu prostorem vidí hůlkou, která určitá spojení umožňuje vytvářet a jiná nikoli. Tyto kompozice nejen rozrušují diskurz o celistvosti a nenarušitelnosti, na kterém stojí představa o zdravém těle (Shakespeare 2006; Goodley 2011), ale dotýká se konkrétních situací, které ukazují vztah mezi tělem a jeho okolím a nejasné hranice, které tělo tvoří.

Se všemi čtyřmi komunikačními partnerkami a partnery, se kterými jsem se setkávala opakovaně, jsem chodila i jako jejich fyzický doprovod. Existují dva hlavní způsoby, jak se nevidomý člověk s vidícím doprovodem fyzicky propojí. Jedním z nich je, že člověk, který nevidí, přiloží svou dlaň na spodní stranu lokte člověka vidícího - takové spojení slouží zejména k orientaci. Druhý způsob, který zároveň preferovali lidé z mého výzkumu, je klasické zavěšení se za rámě. Takové propojení neslouží pouze k určení směru, ale umožňuje i fyzickou oporu.

Zároveň se nejedná pouze o proměnu tělesných hranic nevidomého člověka, ale rovněž člověka vidícího.

Když jdu s nevidomým člověkem, vzájemně se přizpůsobujeme. Pohybujeme se stejnou rychlostí, jdeme stejným směrem. Já vidím, naviguji, nicméně trasou se pohybujeme společně. V některých situacích je třeba přizpůsobit trasu, aby nebyla pro nevidícího člověka př́liš obtížná, ale zároveň aby nebyla moc obtížná ani pro mě. Musím mít na paměti, abychom se někde vešli společně, ale je třeba přizpůsobit trasu i terénu. To byl případ výletu v přírodě, kde jsme šly s Evou. Cesta byla úzká a kamenitá, hlavně jsem vybírala cestu, která by byla pro Evu co nejméně obtížná, ale zároveň kterou bych zvládla i já. Tak jak se jindy dívám pod nohy sobě, bylo důležité i sledovat, kam šlape ona. Orientace na trase byla kombinací hlášení, kde je jaký větší kámen, a fyzického spojení nejen navádějícího na trasu, ale právě i jako fyzické opory, aby se za mě mohla Eva zapřít a abych jí udržela, když na kamenech zavrávorala. Zbytek cesty šla Eva radši s Filipem, který je větší a silnější než já a Eva má u něj větší jistotu, že ji udrží. (terénní poznámky; 21. 11. 2016)

Nejsou to tedy pouze mé oči, které v našem propojení figurují, ale je to celé mé tělo, které je se zrakem spojené a se kterým je propojené další tělo. Spojení těl ovlivňuje jejich rychlosti, udržuje jejich vzájemnou ko-modifikaci a vytváří sloučeninu těl (Shores 2012: 199). Musím určitým zpo̊sobem nastavit ruku, napnout v ní svaly, když je potřeba, jít odlišným způsobem, než kdybych šla sama. To stejné platí i pro Evu. Naučit se chodit s nevidomým člověkem vyžaduje cvik a praxi, při nichž se těla vzájemně přizpůsobují - vznikne mezi nimi kombinace, která jim pak umožňuje pohybovat se společně, což bývá z počátku obtížné. Sžívání se, společné zkušenosti i vzájemné poznávání se vyžaduje množství času, opakování a zkoušení. V českém překladu slova „sít“، se ztratí podstatná část principu ANT - slovo „work“, práce. 
Nejde pouze o propojování a heterogenitu, ale o to, co umožní aktérství (Latour 2005: 143). Každý pohyb - akce - vyžaduje množství práce a záleží na tom, kolik zabere času, jakých nabývá forem (např. Eva tráví s Nessie co nejvíc času, i když Evu právě nevodí), jestli je snadná či obtížná, kdy se něco pokazí a kdy je potřeba začít znovu.

Jak funguje propojení s Nessie, popsala Eva následovně:

Zásadní rozdíl je, že na tom pevným v kombinaci s vodítkem je cítit úplně všechno, co Nessina dělá. Takže já i cítím, že se podívala doleva nebo že očuchává patník, a to s tím volným postrojem není cítit (anebo minimálně já to necítím). A díky tomu pevnýmu postroji, který tak dobře přenáší každej Nessiein pohyb se právě vůbec necítím nejistá, když jdu. Nemám ten pocit, že jdu do prázdnoty, který mám, když jdu v neznámým prostředí sama bez psa, něčí pomoci nebo hůlky. (e-mail; 13. 3. 2015)

Co Nessie dělá, to Eva cítí, a nejde tak pouze o vodění (i na volném postroji pes dovede na místo), ale o rozšíření těla, rozšíření hmatu právě o Nessiein zrak. Zrak není jen nehybnou složkou, která do kompozice Eva-Nessie vstupuje. Pro Evu by nebyl užitečný, kdyby Nessie nebyla vycvičená, nebot' pouze zrak, který je součástí vytrénované sítě, může být její ústřední složkou. Pro Evu je důležitá též možnost se o Nessie fyzicky opřít, a přestože lze k vodění vycvičit i psa malého, velikost a konstituce psa jsou pro získání jistoty podstatné.

Princip sítě stojí na tom, že proměňuje své původní části, v tomto případě naše těla, která získávají novou kvalitu. Současně s tím se proměňuje i trasa, ono kudy, které musí být přizpůsobené nám obou. To samé platí i u výcviku vodícího psa, při kterém se psi musí naučit, že je nutné vybírat společnou cestu - pes tak nemůže jít tudy, kudy by sice sám bez problémů prošel, ale společně s člověkem už ne. Ovšem stejně tak musí Eva dbát na to, co zvládne či nezvládne Nessie.

(vyšli jsme z obchodu, jedeme po eskalátoru, Filip vede Nessie)

Já na Evu: To se speciálně cvičí to chození po jezdících schodech?

Eva: No, ale u Nessiny se to nepovedlo, pořád se bojí.

Já: Jsou psi, který to zvládaj v pohodě?

Eva: Všichni, kromě naší Nessiny.

Já: Troufneš si s ní jít sama ty?

Eva: Ne, sama bych si s ní na eskalátor rozhodně netroufla, protože by to byla asi tragédie.

(terénní poznámky, 15. 10. 2014)

Klíčovou otázkou je, co tato společná konfigurace umožňuje, od čehož se odvíjí i výběr trasy a její zažívání. Nessie navíc očichává patníky, a ne vždy se koncentruje jen na cestu. Přestože se Eva může při vodění na Nessie spolehnout a ví, že s postrojem se nenechá tolik rozrušit psími záležitostmi, zároveň chápe, že ji může nějaký pach zlákat, a podobné zastávky jí nevadí. Princip sítě je symbiózou holismu s fragmentací - sít’ je vzájemně provázána, ale její součást může navázat další spojení, které má vliv na její fungování. Nelze tak pojímat Nessiein zrak jako substituci za chybějící zrak Evy - její zrak by dělal něco jiného a vytvářel odlišná spojení než zrak vodícího psa. Nessie byla Evě přidaná, vytvořila s ní další spojení, ale nenahradila její zrak. 
Zrak není poslušnou funkcí vždy zajišt'ující dobré přechody, ale může být naopak zdrojem rozpojení, zmatení a ztráty orientace. Tak jako množství lidí koukajících do svých telefonů, ani Nessie se někdy nedívá pouze na cestu.

Eva: Byly sme na vodící soutěži, ale skončily sme předposlední.

Já: Jak je to možný? Mně přijdete šikovný spolu.

Eva: (...) A my sme došly nazpátek a šly se dvě trasy, mezitím si došla na to náměstí a čekala se mnou tam ta cvičitelka, až dorazí ta druhá, aby si mě převzala. A mamka, protože by furt každýmu pomáhala, aby kvůli mně někde někdo neměl nějaký problémy, tak jak viděla, že tam se mnou někdo čeká, tak vystartovala, že tam se mnou počká. Ta cvičitelka řekla, jděte pryč, my sme ještě na trase, my ještě trénujeme. A jak Nessina uviděla, že tam je ta mamka, tak za ní chtěla běžet a od té doby už byla hrozně roztržitá a nevodila a chtěla za babičkou. Jak se chová jinak inteligentně, tak tam táhla, chodila přes trávníky... (rozhovor; 15. 10. 2014)

Zrak je součástí těla a jako takový v těle - v tomto př́ipadě v tělech - něco dělá, a to podle toho, s čím se spojí. Zatímco většina spojení vodícímu páru k jeho fungování přispívá např. vizuální spojení s překážkou, které se pak Nessie s Evou vyhnou - či mu aspoň nevadí, existují i taková, která celou kompozici rozloží. Když Nessie zpozorovala Evinu matku, její zrak (a spolu s ním čich a sluch) vytvořil spojení, které bylo pro vodící pár nakonec fatální. Ten samý zrak, který je jinak pro Evu užitečný, stál za rozpadem jejich funkčního propojení.

Ne/ohraničenost těla otevírá otázku autonomie a aktérství. Moser (2006) popisuje situaci ochrnutého muže, který může ovládat svůj každodenní život do té míry, do jaké je zapojen do prostředí kontrolního systému v jeho chytré domácnosti. To pak zviditelňuje kolektivní, distribuované aktérství postiženého člověka, které je umožněno, pokud všechny systémy, kabely, přenosy, vysílače i přijímače fungují, zatímco na „normálního, kompetentního aktéra“ (ibid.: 384) je nahlíženo jako na někoho, jehož aktérství je přirozené a nezávislé. Přitom v zásadě se aktérství neliší, je kolektivní vždy. Další propojení se nikdy nenavazují samostatně, ale ve spojení s něčím. Propojení s hůlkou či vysílačem je navíc pouze dočasné a jiná dočasná spojení, např. s člověkem či vodícím psem, umožňují a dělají odlišné věci, dělají je jinak a další zase znemožňují. Dočasnost uspořádání, které ústí v zastavení rychlosti - pohybu - je patrná na př́kladu lidského doprovodu, který se někdy musí na chvíli od nevidomého člověka odpoutat. Tím, jak se přeruší spojení, dva lidé opět fungují samostatně. Pro Evu to ale znamená, že čeká, až se fyzické spojení s vidícím člověkem opět naváže a mohou pokračovat v cestě. Mezitím stojí a nikam nepopochází. Ř́kala, že lidé si neuvědomují, že když nevidí, znamená to i zhoršenou mobilitu. Kde ji člověk postaví nebo posadí, tam zůstane (terénní poznámky; 31. 10. 2016).

Aktérství nespočívá jen v tom dorazit na nějaké místo, ale umožňuje dělat i další věci, které jsou pro některé nevidomé lidi důležité, či alespoň př́ijemné. Zvlášt’ někteří lidé, kteří dříve viděli, si nechávají rádi popisovat okolí kvůli získání představy a informací o prostředí, ve kterém se pohybují. To je především př́ípad Evy, která touží po nových informacích, a ono kudy tak tedy není pouze o tom dostat se v pořádku z místa na místo, ale o trase se operativně něco dalšího dozvědět, což jí může zprostředkovat jen vidící doprovod. 
Eva říkala, že s Filipem zkusili možnost, aby ji Nessie vedla a on navigoval. Jenže když byl plně zaměstnaný tím říkat jí doleva či doprava, neměl čas jí popisovat a vyprávět o cestě, po které se pohybovali. To jim nevyhovovalo. Eva má známou, která to takto s lidmi dělá, že pes jí vodí a člověk říká, kam má zahnout. Když šli jednou s Filipem za nimi, tak Filip Evě vyprávěl spoustu informací a její známá se o okolí nedozvěděla zdaleka tolik, co Eva, přestože ji doprovázel kromě psa i člověk. (terénní poznámky, 8. 5. 2016)

Zkušenost s trasou tak byla u Evy a její známé odlišná na základě toho, jaké konfigurace vytvářely a co díky těmto spojením mohly a chtěly dělat. Eva mi říkala, že si užívá Filipovy popisy více než popisy některých jiných lidí. Zkušenost se tedy nemění pouze podle toho, zda jde člověk s hůlkou, psem, člověkem či jejich kombinacemi, ale liší se i podle toho, s jak dlouhou hůlkou, s jakým psem i jakým člověkem. Každý člověk také zabírá jiný prostor a dohlédne do jiných míst.

Spojení, kdy je konání dosahováno v součinnosti s dalším člověkem či např. vodícím psem vyžadují důvěru, což se vzpírá modernistickému diskurzu o nezávislém, racionálním a autonomním subjektu (Williams 2005). Eva o své vodící fence ř́íá:

Hned od začátku jsem jí věřila. Já ale vlastně vůbec nemám s důvěrou nějaký problém. Spíš se většinou lidi diví, že jim věřím, že mi v čas řeknou schod anebo že mě někde nevybourají. Ale co jinýho mi zbývá, že jo. Tak pokud jde o vodění, tak věřím lidem i Nessině. A je pravda, že Nessie mi ještě žádný větší karambol nepřivodila. A když už mě nechá vrazit do dopravní značky nebo spadnout z chodníku, tak to je jenom proto, že kouká po cizích psech nebo čuchá nějaké psí novinky. (e-mail; 3. 3. 2015)

Důvěra neznamená naprosté předvídání a možnost se spolehnout na to, že Eva ví, co Nessie a lidé udělají, ale naopak počítat i s tím, že mohou udělat něco jiného: pes se nechá vyrušit psími záležitostmi a člověk zapomene nahlásit schody (což se stalo i mně). Magnus (2014) říká, že důvěra v sobě obsahuje i element risku a vědomí, že zvíře není plně kontrolovatelné člověkem. Tento risk se podstupuje i s dalším člověkem. Prvek důvěry se netýká pouze lidí s postižením, ale disabilita jej zvýznamňuje. Ti samí lidé, kteří se Evě diví, že jim věří, důvěřují ve množství dalších inter-závislostí, které jsou ale banální a tuctové, a proto často neviditelné. Synek, Hradcová, Jahodová a Carboch (2018) poznamenávají, že důvěra se nabývá a posiluje opakováním činností - pro Evu žádná z kolizí nebyla tak zásadní, aby ji odradila v tom pouštět se do podobných situací znovu. Naproti tomu Roman kvůli neblahým zkušenostem s lidmi dnes trvá na tom, že si hůlku vezme i s kamarády či holkami. Zatímco Evu i Jessie lze poměrně snadno udržet a větší kolizi tak předejít, u téměř stokilového Romana to jde těžko.

Spojenectví se psem otevírá nutnost redefinovat některé zažité představy o zvířeti. Taylor (2013), Haslam (2006) a Rasmussen (2011) zdůrazňují, že hranice oddělující lidi a zvírata leží ve specifických charakteristikách, kterými jsou obdařeni pouze lidé a které odkazují k principům potvrzujícím lidskou nadvládu. Není náhodou, že některé z těchto klíčových rysů jsou charakteristiky moderního subjektu postaveného na racionalitě a schopnosti autonomního rozhodování (Williams 2005), tedy na něčem, co je považováno za výhradně lidské. Zvířata 
slouží jako „,,konstitutivní vnějšek‘ či negativní př́íklad, který umožňuje definovat lidskou subjektivitu jako odtělesněnou a autonomní“ (Rasmussen 2011: 101). Pro Evu je důležitá ochota přiznat Nessie schopnosti, které zasahují do lidské sféry.

Mně asi nejvíc v poslední době překvapila tím, že jsem zjistila, že jí nemám mluvit do vodění, protože ona sama nejlíp ví, kam jde. Třeba když jsem na fakultě X, tak jsem měla potřebu jí ríkat, kam má zabočit a tak a ted' v únoru jsem konečně přišla na to, že to dělat nemám. Když jí naviguji, tak se vždycky ztratíme, zato když to nechám všechno na ní, tak se neztratíme. Ona prostě ví, kam mě vede a já začnu zmatkovat, navigovat jí někam jinam a ona mě teda poslechne a většinou to nedopadne dobře. Nessie je přesvědčená, kam chci jít, a je nejlepší, když se jí do toho nepletu. (e-mail; 19. 3. 2016 a 21.3. 2016)

Jasné oddělení toho, kdo vede a kdo je voděný, je neřešitelná otázka. Postižení představuje dynamický fenomén, který je na jednu stranu ztělesněním hegemonních diskurzů o zdraví a těle, ale zároveň je podhoubím i aktérem mnoha subverzivních procesů. Díky tomu, že je postižení neobvyklé a vystupuje $\mathrm{z}$ jednoho normativního rámce, postupně rozrušuje i rámce další. Shildrick (2009: 125-145) či Goodley, Lawthom a Runswick (2014: 347-350) hovoří o postižení jako o prostoru, který otevírá nové cesty stávání se, jež unikají z normativní organizace. Vzniklá propojení mezi heterogenními prvky znamenají rozostření jejich vzájemných hranic, na kterých je přitom vystavěno moderní myšlení - tím je především oddělení prírody a společnosti (Latour 2002). Tedy člověka a zvířete, potažmo člověka a technologie a konečně i zviŕrete a technologie.

Sociolog Michalko (1999), který napsal autobiografickou knihu o zkušenosti s vodícím psem Smokiem, píše: „Často jsme srovnáváni s ostatními týmy člověka a vodícího psa, já jsem srovnáván s ostatními nevidomými a Smokie s ostatními vodícími psy“ (ibid.: 54). Nicméně nestačí analyzovat „vstupní elementy“, potažmo srovnávat člověka s člověkem a psa se psem. Je důležité zkoumat člověka s jeho vodícím psem nikoli odděleně, ale pouze spolu; nejedná se o součet či násobení původních kvalit, ale o vznik kvalit nových na základě jejich vzájemného propojení. Touto novou kvalitou je pak samotné vodění. Lestel, Brunois a Gaunet (2006: 170) připomínají, že naše pozornost nemůže být redukovaná na lidské či zvířecí chování či na reprezentace, které lidé o zviŕăatech mají. Důležité je zaměřit se na to, jak se lidé a zviŕrata chovají spolu, jak tvoří „lidsko-psí entitu“.

Aktérství tak v př́ípadě postiženého člověka přináší redefinici tohoto pojmu, když zviditelňuje sít' dalších aktérů, která v př́ípadě člověka zdatného, tj. zdatného proplouvat mezi normálními přechody, zůstává v pozadí. Moser (2006: 384) si všímá toho, jak se o technologiích, které využívají lidé s postižením, hovoří odlišně, jako o „,asistenčních technologiích“ či „technických pomůckách“, tedy něčeho, co vyjadřuje dorovnání nějakého nedostatku.

Přestože je využívání technologií často pojímáno jako něco navíc, lidé s různými postiženími zažívají naopak technologický deficit. Když jsem se Milana ptala na to, v čem spatřuje rozdíl mezi vidícími a nevidícími lidmi, právě technologie hrály v jeho odpovědi ústřední roli. 
Já: Přijde ti ten život složitější?

Milan: Když to srovnám s těma vidícíma, tak možná trošku jo, no.

Já: V čem?

Milan: No... (ticho)... Kupř́kladu jdou do trafiky, můžou si tam koupit časopis, kterej chtěj, maj ho hned. Nebo si pučej noty, jdou si je okopírovat, je to hotový, otázka dvou minut, i mín. Ale když si jdu oskenovat nějakou knihu, tak mám zabitý dva dny, včetně oprav.

(rozhovor; 8. 11. 2014)

Trafika, časopis, noty i kopírka jsou lidské výtvory, které byly vynalezeny vidícími lidmi pro vidící lidi. Samožrejmě ne všechny činnosti, které nevidomí či vidící lidé vykonávají, souvisí s technologiemi, nicméně lidské společnosti jsou na vynálezech postavené, a právě jejich nedostupnost, tj. neschopnost vytvořit s nimi spojení, se výrazně podílí na konstrukci disability. Při jejím studiu je proto třeba technologii zahrnout (Blume, Galis a Pineda 2013; Casey, Brady a Guerin 2013), přestože její pozitivní př́ínos může být sporný, a to především kvůli tomu, že není všeobecně dostupná (Howe 2011). Při pohybu prostorem nejde jen o design prostředí, chodníků, silnic, semaforů, zábradlí či přechodů pro chodce, ale i dopravních značek, nápisů, jmen ulic či tvorbu map, která tento prostor zdánlivě odráží.

Kolektivnost aktérství ale neznamená, že výrazy jako samostatnost či sám/sama se postižených lidí netýkají. Jen se komplikují, dostávají odlišné kontury zviditelňuje se kontradikce mezi kolektivní aktérstvím a představou o autonomním subjektu a ohraničeném těle.

Roman vyjadřuje nezávislost a samostatnost především tím, že i s asistenty či asistentkami preferuje chození bez fyzického kontaktu, tedy pouze za př́tomnosti toho člověka. To zpočátku naráželo na institucionální pravidla v Organizaci, nicméně její zaměstnankyně Renata poznamenává, že ne vždycky to musí bejt úředně předpisově, jak nás to učí na začátku na školení (rozhovor; 13. 10. 2014). Záleží především na konkrétních osobách, zda tato institucionální nastavení poruší a úzus vznikne společně s konkrétním člověkem.

Kontradikce, která je způsobená narušením jednoty těla, vyvolává bílá hůlka. Ta není pouze nástroj $\mathrm{k}$ orientaci či výrazová funkce dávající najevo, že dotyčný nevidí, ale pojí se i s diskurzem samostatnosti a zodpovědnosti. To se vyjevuje i v prípadě, kdy se k propojení hůlka - nevidící člověk přidá ještě člověk vidící. Orientaci má sice na starost zejména on/a, přesto není pouze na něm či na ní, aby trasu ohlídal/a.

Milan: Ta hůl vede $\mathrm{k}$ samostatnosti, už si nedovedu představit, že bych i s průvodcem šel bez hole. Dřív jsem to praktikoval, když mi bylo tak devět, ale to jsem o chůzi s bílou holí moc nevěděl. (...) Naučili mě to ve škole, že člověk i s průvodcem má tu hůl mít sice v takový pasivnější poloze, v tužkovym držení a má jí mít šikmo před sebou, může se totiž stát, že ten průvodce koukne někam jinam a občas se může stát, že to neuhlídá. A na tom nevidomym je, aby si tu překážku uhlídal. (rozhovor; 19. 10. 2014)

Zrak vidícího člověka není jednoduchou náhradou za zrak člověka nevidomého, ale vede k vytváření spojení jiného druhu - napřs. skrze informace. Nevidomý člověk si může spojnice ohlídat i držením hůlky a nespoléhat tak v jejich vytváření plně na člověka, který vidí. Diskurz samostatnosti, který hůlka $v$ tomto př́padě představuje, ale není přijímán jednoznačně 
pozitivně. Bílá hůl vysílá ambivalentní poselství - jedná se jak o symbol samostatnosti, tak o symbol postižení, které je se samostatností často v rozporu. Nevidomý člověk s hůlkou je často ten, o kterém panuje představa, že potřebuje pomoc, a vzbuzuje lítost (Fourie 2007), naproti tomu např. ve spojení s vodícím psem dostává i sociální rovina postižení odlišné kontury. Zaprvé se zdá, že je tato pomoc již „zajištěna“ a vyvazuje tak nevidomého člověka z patronizujícího př́istupu, a vodící pes na rozdíl od hůlky nepřináší tolik negativních konotací, které člověka často vydělují ze sféry normality. Hůlka představuje něco cizího, znamená cizorodý prvek přináležící pouze $\mathrm{k}$ nevidomému člověku, na druhou stranu pes patř́i i $\mathrm{k}$ člověku běžnému a znamená tak př́stup $\mathrm{k}$ „neznámému postižení“ skrz něco známého a u mnoha lidí oblíbeného. Vodící pes prolamuje počáteční ledy a poskytuje množství konverzačních témat (Bohan a James 2015). Často působí vítané rozptýlení zejména v prostorech, kam jinak zvírata nemají přístup. Nicméně někdy může pozornost, kterou vodící pes vzbuzuje, přerůst až v zastínění nevidomých lidí jejich psím doprovodem (Whitmarsh 2005). Navíc zdaleka ne všude je prŕtomnost vodícího psa tak pozitivně přijímaná jako v euro-americkém kontextu (Bohan a James 2015).

\section{Závěr}

Uvažovat o disabilitě jako vytvářené konkrétními konfiguracemi sítě znamená propojit ji i s prostorem, v němž se nevidomý člověk pohybuje, a který zároveň vytváŕí. Místo objektivizujícího zdravotního postižení či sociálních významů disability se tak perspektiva vycházející z ANT zaměří na to, které přechody je člověk ne/schopný uskutečňovat a jak snadno či obtížně se tak děje. Tyto přechody jsou ve městě vždy materiálně-diskurzivní. Do jejich podoby se promítá představa o zdravém, schopném člověku, pro kterého jsou ony přechody připraveny - a pro člověka, který takto standardizovaný není, jsou obtížné či nemožné.

Uspořádání prostoru a specifických přechodů se promítá i do koncepce aktérství, které díky snadností přechodů pro „zdatného“ člověka vytváŕí dojem, že je autonomním výsledkem jednotlivých subjektů. Disabilita naproti tomu zviditelňuje kolektivní aktérství, vždy navázané na předchozí spojení, díky kterým lze další propojení vytvářet a přechody uskutečňovat. Vždy záleží na tom, jaká uspořádání člověk tvoří - zda s hủlkou, vodícím psem, dalším člověkem, jejich kombinacemi či se pohybuje díky zraku. Na specifických konfiguracích záleží v každé situaci. Přechody se komplikují a zviditelňují, když se člověk jakkoli vymyká standardizované tělesnosti, at' už jde s kočárkem, jede na skateboardu, nebo je zkrátka př́liš mladý či př́lišs starý na snadné navázání určitých spojení. Na základě jednotlivých konstelací se uzpůsobuje i trasa, která vypadá jinak - všímá si jiných záchytných bodů, ř́́dí se dle jiné logiky, sleduje specifické linie a jsou v ní důležité a dostupné jiné informace.

Každý je někdy uschopněný či zneschopněný, což však neznamená, že disabilita/postižení se týká nás všech. Je důležité i to, jak se o konkrétních činnostech mluví (napřs. „asistenční technologie“) a diskurz postižení se nezakládá pouze na ne/schopnosti provést určité aktivity, ale i na způsobech, jakým se provádějí. Lidé, kteří jsou tzv. postižení, většinu činností také vykonávají, ale dělají je jinak a díky jiným spojením než lidé tzv. zdraví. Člověk, který očima nevidí, nemůže tvořit některá spojení, která může vytvářet vidící člověk. Může však vytvářet jiná. A tato spojení mohou nabourávat zažité představy o tom, co znamená číst, poznávat či se pohybovat prostorem. 


\section{Literatura}

ADAM, Tas a Arthur TATNALL. 2010. „Use of ICT to Assist Students with Learning Difficulties: An actor-network Analysis." IFIP Advances in Information and Communication Technology 324: $1-11$.

ADAMS, Rachel. 2013. „Disability Studies Now.“ American Literary History 25(2): 495-507.

BLUME, Stuart, Vasilis GALIS, Andrés Valderrama PINEDA. 2013. „Introduction: STS and Disability." Science, Technology \& Human Values 39(1): 98-104.

BOHAN, Danial Bin a Chan Tuck Wah JAMES. 2015. „Mobility of a Guide Dog Team in Singapore: A Case Study.“ British Journal of Visual Impairment 33(1): 54-65.

BRADLEY, Robert, Teresa HOPKINS a J. M. BAILEY. 2000. „A Study of the Influence of Visual Impairment on the Purchase of Clothing.“ The British Journal of Visual Impairment 18: 79-81.

CAMPBELL, Fiona Kumari. 2009. Contours of Ableism: The Production of Disability and Abledness. New York: Palgrave Macmillan.

CASEY, Hilary, Brady NUALA, Suzanne GUERIN. 2013. „Is Seeing Perceiving?‘ Exploring Issues Concerning Access to Public Transport For People With Sight Loss.“ British Journal of Visual Impairment 31(3): 217-227.

CERTEAU, Michel de. 1984. The Practice of Everyday Life. Berkeley: University of California Press.

CORKER, Mairian. 1999. „Differences, Conflations and Foundations: The Limits to ,Accurate“ Theoretical Representation of Disabled People's Experience?" Disability \& Society 14(5): 627-642.

FOURIE, Robert James. 2007. „A Qualitative Self-study of Retinitis Pigmentosa.“ The British Journal of Visual Impairment 25(3): 217-232.

FRYER, Louise, Jonathan FREEMAN a Linda PRING. 2013. „What Verbal Orientation Information Do Blind and Partially Sighted People Need to Find Their Way Around? A Study of Everyday Navigation Strategies in People with Impaired Vision.“ British Journal of Visual Impairment 31(2): 123-138.

FUCHS, Thomas. 2013. „The Phenomenology of Body Memory.“Pp. 9-22 in Sabine C. KOCH, Thomas FUCHS, Michela SUMMA a Cornelia MÜLLER (eds.). Body Memory, Metaphor and Movement. Amsterdam: Benjamins.

GALIS, Vasilis. 2011. „Enacting Disability: How Can Science and Technology Studies Inform Disability Studies?" Disability \& Society. 26(7): 825-838.

GOODLEY, Dan. 2011. Disability Studies: An Interdisciplinary Introduction. London: Sage Pub.

GOODLEY, Dan, Rebecca LAWTHOM, Katherine RUNSWICK-COLE. 2014. „Posthuman Disability Studies.“ Subjectivity 7(4): 342-361.

GREENHOUGH, Beth. 2010. „Vitalist Geogprahies: Life and the More-Than-Human.“ Pp. 37-55 in Ben ANDERSON a Paul HARRISON (eds.). Taking-Place: Non-Representational theories and Geography. Farnham, Burlington: Ashgate.

HASLAM, Nick. 2006. „Dehumanization: An Integrative Review.“ Personality and Social Psychology Review: An Official Journal of the Society for Personality and Social Psychology, Inc. 10(3): 252-64.

HOWE, P. David. 2011. „Cyborg and Supercrip: The Paralympics Technology and the (Dis)empowerment of Disabled Athletes.“ Sociology 45(5): 868-882.

KOLÁŘOVÁ, Kateřina. 2012. „Tělesná jinakost, ne/způsobilost, ,postižení‘, hendikep... K politice překladu a teoretickému vymezení pojmů.“Pp. 41-63 in Kateřina KOLÁŘOVÁ (ed.). Jinakost postižení - kritika: společenské konstrukty nezpiosobilosti a hendikepu: antologie textů z oboru disability studies. Praha: Sociologické nakladatelství (SLON).

LATOUR, Bruno. 1999. „On Recalling ANT.“ The Sociological Review 47(1): 15-25.

LATOUR, Bruno. 2002. We Have Never Been Modern. Cambridge, MA: Harvard University Press.

LATOUR, Bruno. 2005. Reassembling the Social: An Introduction to Actor-network-theory. Oxford: Oxford University Press. 
LESTEL, Dominique a Florence BRUNOIS a Florence GAUNET. 2006. „Etho-ethnology and Ethno-ethology.“ Social Science Information 45(2): 155-177.

MAGNUS, Riin. 2014. „The Role of Trust in Binding the Perspectives of Guide Dogs and Their Visually Impaired Handlers.“ Sign Systems Studies 42(2-3): 376-398.

MALINS, Peta. 2004. „Machinic Assemblages: Deleuze, Guattari and an Ethico-Aesthetics of Drug Use.“ Janus Head 7(1): 84-104.

MAULDIN, Laura. 2017. „A Feminist Technoscientific Approach to Disability and Caregiving in the Family.“ Pp. 139-161 in Michael REMBIS (ed.). Disabling Domesticity. New York: Palgrave Macmillan.

MICHALKO, Rod. 1999. The Two-in-One Walking with Smokie, Walking with Blindness. Philadelphia: Temple University Press.

MOSER, Ingunn. 2005. „On Becoming Disabled and Articulating Alternatives.“ Cultural Studies 19(6): $667-700$.

MOSER, Ingunn. 2006. „Disability and the Promises of Technology: Technology, Subjectivity and Embodiment Within an Order of the Normal." Information, Communication and Society 9(3): 373-395.

MOSER, Ingunn a John LAW. 1998. „Přechody snadné, přechody nesnadné.“ Biograf 15-16. Retrieved June 26, 2017 (http://www.biograf.org/clanek.php?clanek=1502).

MURDOCH, Jonathan. 1997. „Towards a Geography of Heterogeneous Associations.“ Progress in Human Geography 21(3): 321-37.

OLIVER, Mike. 1983. Social Work with Disabled People. Basingstoke: Macmillan.

OSMAN, Robert a Lucie POSPÍŠILOVÁ. 2016. „Zkušenost bez zraku: Př́ležitost pro reflexi prostorového normativu.“ Gender, Rovné Př́ležitosti, Výzkum 17(1): 63-76.

OSMAN, Robert a Lucie POSPÍŠILOVÁ. 2017. „Po paměti/geografie nevidomých.“ in Robert OSMAN a Lucie POSPÍŠILOVÁ (eds.). Geografie Okrajem. Praha: Karolinum. V tisku.

RASMUSSEN, Claire E. 2011. The Autonomous Animal: Self-Governance and the Modern Subject. Minneapolis: University of Minnesota Press.

SCHILLMEIER, Michael. 2008. „Time-spaces of In/dependence and Dis/ability.“ Time \& Society 17: 215-231.

SHAKESPEARE, Tom. 2006. Disability Rights and Wrongs. London: Routledge.

SHILDRICK, Margrit. 2009. Dangerous Discourses of Disability, Subjectivity and Sexuality. Basingstoke: Palgrave Macmillan.

SHORES, Corry. 2012. „Body and World in Merleau-Ponty and Deleuze.“ Studia Phaenomenologica 12: 181-209.

SMITH, Richard. 2007. „Poststructuralism, Power and the Global City.“ Pp. 249-260 in P. J. TAYLOR (ed.). Cities in Globalization: Practices, Policies and Theories. London: Routledge.

STÖCKELOVÁ, Tereza. 2016. „Předmluva. Latourova společenskovědní laboratoř.“ Pp. 7-11 in Tereza STÖCKELOVÁ (ed.). Stopovat a skládat světy s Brunem Latourem. Výbor z textů 1998-2013. Praha: Tranzit.cz.

STRICKFADEN, Megan. DEVLIEGER, Patrick. 2012. „Reversing the (Im)material Sense of a Nonplace: The Impact of Blindness on the Brussels Metro." Space and Culture 15(3): 224-238.

SYNEK, Michal. 2018. „Perfect Etiquette. On Diplomatically Arguing with Members.“ Medicine Anthropology Theory 5(1). doi.org/10.17157/mat.5.1.500.

SYNEK, Michal a Radek CARBOCH. 2014. „Profesní slepota a režimy spěchu: Podpora soběstačnosti při jídle v institucionální péči o lidi s mentálním znevýhodněním.“ Biograf (60): 59 odst. Citováno 20. dubna, 2018 (http://www.biograf.org/clanek.html?clanek=6001).

SYNEK, Michal, Dana HRADCOVÁ, Dita JAHODOVÁ a Radek CARBOCH. 2017. „O (ne)soudržnosti pečování: Mnohočetné ontologie života s demencí.“ Biograf 65-66: 5-51. 
TAYLOR, Nik. 2013. Humans, Animals, and Society: An Introduction to Human-animal Studies. New York: Lantern Books.

TREMAIN, Shelley. 2006. „Reproductive Freedom, Self-Regulation, and the Government of Impairment in Utero." Hypatia: A Journal of Feminist Philosophy 21(1): 35-53.

WHITMARSH, Lorraine. 2005. „The Benefits of Guide Dog Ownership.“ Visual Impairment Research 7(1): 27-42.

WILliAMS, Caroline. 2005. Contemporary French Philosophy: Modernity and the Persistence of the Subject. London: Continuum.

\section{Internetový zdroj}

Ovladač dálkový VPN 02. Nedatováno. Citováno 2. března, 2018 (http://www.tyflopomucky.cz/ olomouc/elektronicke-pomucky/1074-Ovladac-dalkovy-VPN-02.html).

\section{Zákon}

Zákon č. 128/2000 sb., zákon o obcích.

\section{Autorka}

Hana Porkertová vystudovala sociologii na Fakultě sociálních studií Masarykovy univerzity v Brně, kde obhájila disertační práci zabývající se nevidomou zkušeností. V současné době působí jako odborná asistentka na Ústavu práva a humanitních věd Mendelovy univerzity v Brně. Zaměřuje se na sociologii tělesnosti a konstrukci disability, ke kterým přistupuje z poststrukturalistické pozice.

Kontakt: h.porkertova@gmail.com 